\title{
Theory Of Planned Behavior Implementation (Planned Behavior) In Mother Behavior In Postpartum Care In The House Of Mother's Children Fauziah Tulungagung
}

\author{
Biedasari Emi Chandra \\ Graduate Program STIKes Surya Mitra Husada Kediri \\ Bidastikeshah@gmail.com
}

\begin{abstract}
Postpartum or puerperium begins 1 hour after birth of the placenta up to 6 weeks (42 days) afterwards. Parents, especially mothers, need to have the knowledge and readiness to conceive, give birth and breastfeed children. One of the factors that can cause maternal death is complications that occur during the puerperium. Postpartum complications of the highest incidence rate in Indonesia are bleeding and infection. This research is an observational analytic research with cross sectional approach. In the cross-sectional study, the researchers conducted observations or measurements of variables at one particular moment. Measurement of variables in one moment does not mean that all objects are observed exactly at the same time, but it means that each subject is observed only once and the measurement of the subject variable is performed during the examination. The results of research based on chi square test showed a significant influence that is attitude $\rho=0,18$ where $\rho>\alpha(0,05)$ so that $\mathrm{HO}$ accepted mean no attitude influence. The subjective norm $\rho=0.35>\rho>\alpha(0,05)$ so that HO is accepted which means there is no influence between subjective norms. Ability to control $\rho=0.12>\rho$ $>\alpha(0,05)$ so that $H 0$ is accepted which means there is no influence between the perception of control ability. Interest $\rho=0.96>\rho>\alpha(0.05)$ so that HO is accepted which means there is no influence of interest. The most dominant fator is the education level, $p=0.03>p<\alpha(0.05)$ so that HO is rejected which means there is an influence between the level of education in behavior on postpartum care at Rumah Sakit Ibu Anak Fauziah Tulungagung. The Health Service of Tulungagung through mother's hospital Fauziah is expected to socialize the community about postpartum care so that the public can express the problems especially the mothers without burdened by the existence of panisment such as influence in value and others.
\end{abstract}

Keywords: Planned Behavior, Mother Behavior, Postpartum Care. 


\section{PRELIMINARY}

Postpartum or puerperium begins 1 hour after birth of the placenta up to 6 weeks (42 days) afterwards. Parents, especially mothers, need to have knowledge and readiness to conceive, give birth and breastfeed children.

One of the factors that can cause maternal death is complications that occur during the puerperium. The puerperal complications of the highest incidence rate in Indonesia are bleeding and infection (Wiknjosastro, 2001). Other data mentioned that the direct cause of maternal death related to pregnancy and childbirth is mainly $28 \%$ bleeding, other cause, that is $24 \%$ eclampsi, $11 \%$ infection, $5 \%$ old partus, and abortus 5\% (Ine, 2010).

The research conducted by Rahmawati (2001) on the identification of self-care needs of postpartum women that the complications and health problems that often occur during the puerperium period are $82 \%$ inconvenience, stomach itch (40\%), itching on the perineum (15\%), vaginal discharge $(15 \%)$ and fatigue $(78 \%)$. This can be avoided by providing sufficient knowledge to the mother about early treatment during the puerperium.

The postpartum period is a period of adaptation, both for mother and baby. Mother will have a task that is not light, in addition to meeting the needs of him self, family, mother also caring for newborns. The inability of the mother to understand the baby can result in fatigue. Research conducted by Reitmanova and Gustafson (2007) using a qualitative approach found that after birth the mother felt very tired, felt worries about the needs of her baby and also needed rest. This is also put forward by Liabsuetrakul, Vittayanont and Pitanupong (2007), which states that mothers who experience anxiety and do not get a good support system and experience this continuously without a good support system and adequate knowledge, it will be the trigger factor of the occurrence postpartum blues and postpartum depression.

Postpartum care is in the classification of treatment activities that are educative because individuals can perform self-care. Self-care is an activity in which individuals initiate and implement their own needs (Orem, 2001). The success of independent care depends on the level of maturity, level of knowledge, life experience, habits and mental health conditions (Orem, 2001).

Self-care during the puerperium is necessary to achieve optimal maternal health status. Mothers in the postpartum, often experienced confusion in self-care. Mother confused how to care perineum, how to breast care, and other things related to self care in the postpartum period. If this condition continues to continue then there will likely be a complocation after childbirth. To overcome this, the necessary health education, which is intended to mother in self care during childbirth.

Data obtained by researchers on April 30, 2017, from 15 postpartum patients at RSIA Fauziah Tulungagung, 5 people forgot to forget about portpartum care, and 7 people said they did not know about postpartum care. In response to some of these circumstances, the RSIA Fauziah Tulungagung always provide counseling about the care of postpartum mothers that include; nutritional status, breast care, perineal wound care, surgical wound, early mobilization of every patient present, in the hope of achieving optimal health status in postpartum mothers.

Primipara is the first woman to give birth. The primiparous mother often lacks knowledge and experience in selfcare and her baby. This can lead to the emergence of self-confidence in the inability to care for themselves and babies. Mutability of the mother's 
inability to care for her baby can be an obstacle in providing care and establish good relations with the baby, but the closeness and touch of the mother with the baby is a stimulus that can increase milk production.

To overcome this, the necessary health education, which is intended to memandirikan mother in self care during childbirth. Research conducted by Runiari (2005), about health education material needed by postpartum mother related to maternal care is nutritional requirement or nutrition, perineal care, breast care and episiotomy treatment. Self-care during the puerperium period is needed to help mothers monitor and maintain their health by providing them with appropriate and adequate information and skills, controlling their behavior and making informed decisions.

Health education is a series of efforts aimed at influencing others, ranging from individuals, groups, families and communities to the implementation of healthy living behaviors (Setiawati \& Dermawan, 2008). Health education can be provided with a variety of methods, including: lectures, discussions, giving leaflets, booklets or practices directly related to the needs of the mother.

According to Nyswander (in Susilo, 2011) health education is a process of change in the human self that has to do with the achievement of individual and community health goals. Health education can be provided to minimize the client's ignorance about postpartum care, so that in case of abnormalities, the client may immediately come to the service health.

Health education can be directly given when the client is still in the hospital, ie on the first day or two after the client gave birth. Maternity nurses who act as advocates and educators, have a responsibility to facilitate clients in obtaining information in the form of health education, so the risks or complications of the postpartum can be avoided.

The purpose of health education according to Azwar (in Susilo, 2011) are: behaviors that make health as a valuable in society, independently able to create healthy behavior for themselves as well as create healthy behaviors within the group, encourage the development and use of existing health care facilities appropriately.

Based on the description above, the improvement of postpartum care behavior is very important, but in Indonesia today, there are still mothers who can not do self-care for themselves and their babies. Improvement of mother's behavior on the care of postpartum also has not run optimally. Thus the application of health counseling techniques in the form of postpartum care to affect the mother's behavior.

In one theory of behavior, precisely TRA, Ajzen (in Jogiyanto, 2007), which states that a person can perform or not to do a behavior depends on the intention of the person. Furthermore, Ajzen explains that the intention of performing or not performing a particular behavior is influenced by two basic determinants, the first relating to attitudes (attitude toward behavior) and the other related to the social influence of subjective norms (subjective norms). In an attempt to express the influence of subjective attitudes and norms on the intent to do or not to do the behavior, Ajzen completes this TRA with beliefs (beliefs). He argues that attitudes stem from behavioral beliefs, whereas subjective norms derive from normative beliefs.

In the same year, Ajzen (in Jogiyanto, 2007) added a construct that is not yet in the TRA, perceived behavioral control, through his theory, 
known as Theory of planned behavior. This construct is added in an effort to understand the limitations of the individual in order to perform certain behaviors (Chau \& Hu, 2002). In other words, whether or not a behavior is undertaken is determined not only by subjective attitudes and norms, but also the individual's perception of control that can be exercised that is based on his belief in the control (beliefs). More fully Ajzen (2005) adds individual background factors to perceived behavioral control.

Based on the above background, the researcher is interested to do further research on Implementation of Theory of Planned Behavior (Planned Behavior) in Mother Behavior on the Treatment of Postpartum at Maternal and Fauziah Hospital of Tulungagung Regency.

\section{METHOD}

This research is an observational analytic research with cross sectional approach. In the cross-sectional study, the researchers conducted observations or measurements of variables at one particular moment. Measurement of variables in one moment does not mean that all objects are observed exactly at the same time, but it means that each subject is observed only once and the measurement of subject variables is done during the inspection (Sastroasmoro \& Ismael, 2010).

Population is all subject of research or object with certain characteristic to be studied (Hidayat, 2007). The population in this study were all postpartum women who gave birth normally or pervaginam in RS. Ibu Anak Fauziah Tulungagung in 2 weeks.

The study sample is part of the population under study and is considered to represent the entire population (Notoadmodjo, 2005). The sample in this study based on research criteria.
Sample size based on general considerations and trends with regard to population size. According to Surachmad, et al. 1990 (in Siyoto and Sari, 2016) states that the sample size is largely determined by the size of the population. For populations less than 100 , samples can be taken entirely.

Independent variables in this research are attitude, subjective norm, behavior control, and interest. While the dependent variable in this study is the mother's behavior on postpartum care.

The method of analysis used in this research is descriptive statistical test and hypothesis test by using logistic regression. The use of logistic regression analysis is because the dependent variable is dichotomous (precise and inappropriate). Analytical techniques in processing this data no longer requires the test of normality and test the classical assumption on the independent variables (Ghozali, 2011). In conducting logistic regression analysis, feasibility testing of Regression Model, Assessing Overall Model, Coefficient of Determination, and Simultan eous testing.

The steps taken to fulfill the research ethics are as follows: (a) Informed Consent, (b) Anonymity, (c) Confidentiality (Confidentiality).

Limitations are the weaknesses and obstacles in research (Nursalam, 2007). Obstacles in this study: (a) The study time is very limited, so the samples obtained are limited which is likely the result is less perfect and less satisfactory. (b) The ability of researchers to describe the problem is less, so it is possible this research still needs improvement. (c) Of the many factors behind the behavior change, researchers only use 4 factors, so that possible results are less than the maximum. 


\section{RESEARCH RESULT}

1. Frequency Distribution by Education Level

Table 1 Distribution of Respondent Characteristics Based on Education Level at RS Ibu Anak Fauziah Tulungagung On 16 August to 16 September 2017.

\begin{tabular}{|c|c|c|}
\hline level of education & $\mathrm{N}$ & $\begin{array}{c}\mathrm{f} \\
(\%)\end{array}$ \\
\hline SD & 1 & 4 \\
\hline SMP & 3 & 12 \\
\hline SMA & 16 & 64 \\
\hline PT & 5 & 20 \\
\hline Total & 25 & 100 \\
\hline
\end{tabular}

Source: primary data of the study

Based on table 1 above, shows from 25 respondents most of which are 16 respondents (64\%) have high school education and 1 respondent $(4 \%)$ have elementary education.

2. Frequency Distribution by Type of Work

Table 2 Distribution of Respondent Characteristics by Type of Work at RS Ibu Anak Fauziah Tulungagung On 16 August to 16 September 2017.

\begin{tabular}{lcc}
\hline \multicolumn{1}{c}{ type of work } & $\mathrm{n}$ & $\begin{array}{c}\mathrm{f} \\
(\%)\end{array}$ \\
\hline IRT (housewife) & 14 & 56 \\
Entrepreneur & 2 & 8 \\
Private & 3 & 12 \\
PNS & 1 & 4 \\
Teacher & 3 & 12 \\
Farmers & 2 & 8 \\
Total & 25 & 100 \\
\hline
\end{tabular}

Source: primary data of the study

Based on table 2 above, it shows from 25 respondents most of which are 14 respondents $(56 \%)$ type of housewife job (IRT) and 1 respondent $(4 \%)$ type of work of Civil Servant (PNS).

\section{Frequency Distribution by Category Age}

Table 3 Distribution of Respondent Characteristics by Category of Age at RS Ibu Anak Fauziah Tulungagung On 16 August to 16 September 2017.

\begin{tabular}{lcc}
\hline \multicolumn{1}{c}{ Age category } & $\mathrm{n}$ & $\mathrm{f}(\%)$ \\
& & \\
\hline$<30$ year & 2 & 8 \\
$\geq 30$ year & 23 & 92 \\
Total & 25 & 100 \\
\hline
\end{tabular}

Source: primary data of the study

Based on table 3 above, shows from 25 respondents most of which are 23 respondents (92\%) category > 30 years old and 2 respondents $(8 \%)$ age category $<30$ years.

\section{SPECIFIC DATA}

Specific data presents about attitudes, subjective norms, ability to control, interest in mother's behavior on postpartum care at RSIA Fauziah Tulungagung. These data are the variables that allegedly influence the mother's behavior on postpartum care. The data are detailed in the following table:

\section{Frequency Distribution Based on Attitude}

Table 4 Distribution of Respondents Based on Mother's Attitude in Postpartum Care Behavior at RS Ibu Anak Fauziah Tulungagung on 16 August to 16 September 2017.

\begin{tabular}{|c|c|c|}
\hline Attitude & $\mathrm{n}$ & $f(\%)$ \\
\hline Positif & 15 & 60 \\
\hline Negatif & 10 & 40 \\
\hline Total & 25 & 100 \\
\hline
\end{tabular}

Source: primary data of the study

Based on table 4 above, shows from 25 respondents most of which $(60 \%) 15$ respondents have a positive attitude. 


\section{Frequency Distribution Based on Subjective Norms}

Table 5 Distribution of Respondents Based on Subjective Norms of Mothers In Postpartum Care Behavior at RS Ibu Anak Fauziah Tulungagung On 16 August to 16 September 2017.

\begin{tabular}{lcc}
\hline \multicolumn{1}{c}{ Subjective Norm } & N & $\mathrm{f}(\%)$ \\
\hline well, & 20 & 80 \\
Enough & 4 & 16 \\
Less & 1 & 4 \\
Total & 25 & 100 \\
\hline
\end{tabular}

Source: primary data of the study

Based on table 5 above, shows from 25 respondents most $(80 \%) \quad 20$ respondents have subjective norms in postpartum treatment behavior.

3. Frequency Distribution Based on Perception Control Ability

Table 5 Distribution of Respondents Based on Mother Control Ability in Postpartum Care Behavior at RS Ibu Anak Fauziah Tulungagung on 16 August to 16 September 2017.

\begin{tabular}{lcc}
\hline $\begin{array}{c}\text { Perceptions of Controlling } \\
\text { Ability }\end{array}$ & $\mathrm{N}$ & $\mathrm{f}(\%)$ \\
\hline well, & 11 & 44 \\
Enough & 11 & 44 \\
Less & 3 & 12 \\
Total & 25 & 100 \\
\hline
\end{tabular}

Source: primary data of the study

Based on table 5 above, showing from 25 respondents most (44\%) 11 respondents have perception of control ability in postpartum and good care behavior.

\section{Interest-Based Frequency} Distribution

Table 6 Distribution of Respondents

Based on Mother's Interest in Postpartum Care Behavior at RS Ibu Anak Fauziah Tulungagung On 16 August to 16 September 2017.

\begin{tabular}{lccc}
\hline & Interest & $\mathrm{N}$ & $\mathrm{f}(\%)$ \\
\hline High & & 21 & 84 \\
Medium & & 2 & 8 \\
Low & 2 & 8 \\
& Total & 25 & 100 \\
\hline
\end{tabular}

Source: primary data of the study

Based on table 6 above, shows from 25 respondents most of which are 21 respondents (84\%) interest in mothers in behavior of postpostum care high.

\section{CROSS TABULATION}

\section{Cross tabulation Respondent Characteristics with Respondent Behavior}

a. Cross-tabulation of Education Level with Respondent's Behavior

Table 7 Distribution of Respondents With Maternal Education Levels in Postpartum Mother Behavior at RS Ibu Anak Fauziah Tulungagung On 16 August to 16 September 2017.

\begin{tabular}{|c|c|c|c|c|c|c|c|c|}
\hline \multirow{3}{*}{$\begin{array}{l}\text { level of } \\
\text { education }\end{array}$} & \multicolumn{6}{|c|}{ behavior of respondents } & \multirow{2}{*}{\multicolumn{2}{|c|}{ Total }} \\
\hline & \multicolumn{2}{|c|}{$\begin{array}{l}\text { Less } \\
\leq 55 \%\end{array}$} & \multicolumn{2}{|c|}{$\begin{array}{c}\text { Enough } \\
56 \%-74 \%\end{array}$} & \multicolumn{2}{|c|}{$\begin{array}{c}\text { Less } \\
\geq 75 \%\end{array}$} & & \\
\hline & $\mathrm{N}$ & $\mathrm{F}$ & $\mathrm{N}$ & $\mathrm{F}$ & $\mathrm{N}$ & $\mathrm{F}$ & $\mathrm{N}$ & $\mathrm{F}$ \\
\hline SD & 0 & 0,0 & 1 & 5,6 & 0 & 0,0 & 1 & 4,0 \\
\hline SMP & 0 & 0,0 & 3 & 16,7 & 0 & 0,0 & 3 & 12,0 \\
\hline SMA & 1 & 100,0 & 12 & 66,7 & 3 & 50,0 & 16 & 64,0 \\
\hline PT & 0 & 0,0 & 2 & 11,1 & 3 & 50,0 & 5 & 20,0 \\
\hline $\begin{array}{l}\text { Total } \\
\rho=0,03\end{array}$ & 1 & 100,0 & 18 & 100,0 & 6 & 100,0 & 25 & 100,0 \\
\hline
\end{tabular}

Source: primary data of the study

Based on table 7 shows from 25 respondents, as many as 12 respondents $(66.7 \%)$ have high school education and behave on postpartum care enough category. From Chi Square test result got $\rho=0,03$ where $\rho>\alpha(0,05)$ so that $\mathrm{H} 0$ is rejected which mean that there is influence between education level with mother behavior on post partum care. 


\begin{tabular}{cllllllll}
\hline age category & \multicolumn{9}{c}{ behavior of respondents } & \multirow{2}{*}{ Total } \\
\cline { 2 - 6 } & \multicolumn{2}{c}{$\begin{array}{c}\text { Less } \\
\leq 55 \%\end{array}$} & \multicolumn{2}{c}{$\begin{array}{c}\text { Enough } \\
56 \%-74 \%\end{array}$} & $\begin{array}{c}\text { Less } \\
\geq 75 \%\end{array}$ & & \\
\hline & $\mathrm{N}$ & $\mathrm{F}$ & $\mathrm{N}$ & $\mathrm{F}$ & $\mathrm{N}$ & $\mathrm{F}$ & $\mathrm{N}$ & $\mathrm{F}$ \\
\hline$<30$ year & 0 & 0,0 & 1 & 5,6 & 1 & 16,7 & 2 & 8,0 \\
$\geq 30$ year & 1 & 100,0 & 17 & 94,4 & 5 & 83,3 & 23 & 92,0 \\
Total & 1 & 100,0 & 18 & 100,0 & 6 & 100,0 & 25 & 100,0
\end{tabular}
$\rho=0,37$

\section{b. Cross-tabulation of Work Types with Respondent Behavior}

Table 8 Distribution of Respondents by Type of Work of Mothers In

\begin{tabular}{|c|c|c|c|c|c|c|c|c|}
\hline \multirow[t]{3}{*}{ type of work } & \multicolumn{6}{|c|}{ behavior of respondents } & \multirow{2}{*}{\multicolumn{2}{|c|}{ Total }} \\
\hline & \multicolumn{2}{|c|}{$\begin{array}{c}\text { Less } \\
\leq 55 \%\end{array}$} & \multicolumn{2}{|c|}{$\begin{array}{l}\text { Enough } \\
56 \%-74 \%\end{array}$} & \multicolumn{2}{|c|}{$\begin{array}{l}\text { Less } \\
\geq 75 \%\end{array}$} & & \\
\hline & $\mathrm{N}$ & $\mathrm{F}$ & $\mathrm{N}$ & $\mathrm{F}$ & $\mathrm{N}$ & $F$ & $\mathrm{~N}$ & $F$ \\
\hline IRT & 1 & 100,0 & 9 & 50,0 & 4 & 66,7 & 14 & 56,0 \\
\hline Wiraswasta & 0 & 0,0 & 2 & 11,1 & 0 & 0,0 & 2 & 8,0 \\
\hline Swasta & 0 & 0,0 & 3 & 16,7 & 0 & 0,0 & 3 & 12,0 \\
\hline PNS & 0 & 0,0 & 0 & 0,0 & 1 & 16,7 & 1 & 4,0 \\
\hline Theacher & 0 & 0,0 & 3 & 16,7 & 0 & 0,0 & 3 & 12,0 \\
\hline Farmers & 0 & 0,0 & 1 & 5,6 & 1 & 16,7 & 2 & 8,0 \\
\hline \multirow[t]{6}{*}{$\begin{array}{l}\text { Total } \\
\rho=0,88\end{array}$} & 1 & 100,0 & 18 & 100,0 & 6 & 100,0 & 25 & 100,0 \\
\hline & & & \multicolumn{4}{|c|}{ Postpartum } & \multicolumn{2}{|c|}{ Mother } \\
\hline & & & \multicolumn{4}{|c|}{ Behavior at $\mathrm{RS}$} & $\mathrm{mc}$ & her \\
\hline & & & \multicolumn{4}{|c|}{ and child } & Fau & ah \\
\hline & & & \multicolumn{4}{|c|}{ Tulungagung } & & 16 \\
\hline & & & \multicolumn{6}{|c|}{ August to 16 September } \\
\hline
\end{tabular}

Source: primary data of the study

Based on table 8 shows from 25 respondents, as many as 9 respondents $(50 \%)$ as IRT behaved on postpartum care enough category.From Chi Square test results obtained $\rho=$ 0.88 where $\rho>\alpha(0.05)$ so that $\mathrm{H} 0$ is accepted which means that there is an influence between the type of work and the mother's behavior on postpartum care.

c. Cross tabulation of Age Categories with Respondent Behavior

Table 9 Distribution of Respondents With Mother Age In Postpartum Mother Behavior at RS Ibu Anak Fauziah Tulungagung On 16
September 2017.

Source: primary data of the study

Based on table 9 showing from 25 respondents, 17 respondents $(94 \%)$ were $>30$ years old, behaved on sufficient category postpartum care. From result of Chi square test got $\rho=$ 0,37 where $\rho>\alpha(0,05)$ so that $\mathrm{HO}$ is accepted meaning that there is no influence between age with mother behavior on post partum care.

2. Cross-tabulation of Independent Variables with Respondent Behavior

a. Cross tabulation of Attitudes with Respondent Behavior

Table 10 Distribution of Respondents With Mother's Attitude In Postpartum Mother Behavior at RS Ibu Anak Fauziah Tulungagung On 16 August to 16 September 2017.

\begin{tabular}{ccccccccc}
\hline Attitude & \multicolumn{9}{c}{ behavior of respondents } & \multirow{2}{*}{ Total } \\
\cline { 2 - 6 } Category & \multicolumn{2}{c}{$\begin{array}{c}\text { Less } \\
\leq 55 \%\end{array}$} & \multicolumn{2}{c}{$\begin{array}{c}\text { Enough } \\
56 \%-74 \%\end{array}$} & \multicolumn{2}{c}{$\begin{array}{c}\text { Less } \\
\geq 75 \%\end{array}$} & & \\
\hline & $\mathrm{N}$ & $\mathrm{F}$ & $\mathrm{N}$ & $\mathrm{F}$ & $\mathrm{N}$ & $\mathrm{F}$ & $\mathrm{N}$ & $\mathrm{F}$ \\
\hline Positif & 1 & 100,0 & 9 & 50,0 & 5 & 83,3 & 15 & 60,0 \\
Negatif & 0 & 0 & 9 & 50,0 & 1 & 16,7 & 10 & 40,0 \\
Total & 1 & 100,0 & 18 & 100,0 & 6 & 100,0 & 25 & 100,0 \\
$\rho=0,18$ & & & & & & & & \\
\hline
\end{tabular}

Source: primary data of the study

Based on table 10 showing from 25 respondents, as many as 9 respondents (50\%) have sikappositif and negative and behave on postpartum care enough category. From result of Chi square test got $\rho=0,18$ where $\rho>\alpha(0,05)$ so that $\mathrm{H} 0$ is accepted meaning that there is no influence between attitude with mother behavior on postpartum care. 


\begin{tabular}{|c|c|c|c|c|c|c|c|c|}
\hline \multirow{3}{*}{$\begin{array}{c}\text { Interest } \\
\text { Categorie } \\
\mathrm{s} \\
\end{array}$} & \multicolumn{6}{|c|}{ behavior of respondents } & \multirow{2}{*}{\multicolumn{2}{|c|}{ Total }} \\
\hline & \multicolumn{2}{|c|}{$\begin{array}{c}\text { Less } \\
\leq 55 \%\end{array}$} & \multicolumn{2}{|c|}{$\begin{array}{c}\text { Enough } \\
56 \%-74 \%\end{array}$} & \multicolumn{2}{|c|}{$\begin{array}{c}\text { Less } \\
\geq 75 \%\end{array}$} & & \\
\hline & $\mathrm{N}$ & $\mathrm{F}$ & $\mathrm{N}$ & $\mathrm{F}$ & $\mathrm{N}$ & $\mathrm{F}$ & $\mathrm{N}$ & $F$ \\
\hline Well & 1 & $\begin{array}{l}100, \\
0\end{array}$ & $\begin{array}{l}1 \\
5\end{array}$ & 83,3 & 5 & 83,3 & $\begin{array}{l}2 \\
1\end{array}$ & 84,0 \\
\hline $\begin{array}{l}\text { Enoug } \\
\mathrm{h}\end{array}$ & 0 & 0,0 & 1 & 5,6 & 1 & 16,7 & 2 & 8,0 \\
\hline Less & 0 & 0,0 & 2 & 11,1 & 0 & 0,0 & 2 & 8,0 \\
\hline Total & 1 & $\begin{array}{l}100, \\
0\end{array}$ & $\begin{array}{l}1 \\
8\end{array}$ & $\begin{array}{l}100, \\
0\end{array}$ & 6 & $\begin{array}{l}100, \\
0\end{array}$ & $\begin{array}{l}2 \\
5\end{array}$ & $\begin{array}{l}100, \\
0\end{array}$ \\
\hline
\end{tabular}

b. Cross-tabulation of Subjective Norms with Respondent Behavior

Table 11 Distribution of Respondents With

\begin{tabular}{|c|c|c|c|c|c|c|c|c|}
\hline \multirow{3}{*}{$\begin{array}{l}\text { Category } \\
\text { Perception }\end{array}$} & \multicolumn{6}{|c|}{ behavior of respondents } & & \\
\hline & \multicolumn{2}{|c|}{$\begin{array}{c}\text { Less } \\
\leq 55 \%\end{array}$} & \multicolumn{2}{|c|}{$\begin{array}{c}\text { Enough } \\
56 \%-74 \%\end{array}$} & \multicolumn{2}{|c|}{$\begin{array}{c}\text { Less } \\
\geq 75 \%\end{array}$} & \multicolumn{2}{|c|}{ Total } \\
\hline & $\mathrm{N}$ & $\mathrm{F}$ & $\mathrm{N}$ & $\mathrm{F}$ & $\mathrm{N}$ & $\mathrm{F}$ & $\mathrm{N}$ & $\mathrm{F}$ \\
\hline Well & 0 & 0,0 & 10 & 55,6 & 1 & 16,7 & 11 & 44,0 \\
\hline Enough & 1 & 100,0 & 6 & 33,3 & 4 & 66,6 & 11 & 44,0 \\
\hline Less & 0 & 0,0 & 2 & 11,1 & 1 & 16,7 & 3 & 12,0 \\
\hline Total & 1 & 100,0 & 18 & 100,0 & 6 & 100,0 & 25 & 100,0 \\
\hline
\end{tabular}

Subjective Norms of Mothers In Postpartum Mother Behavior at RS Ibu Anak Fauziah Tulungagung On 16 August to 16 September 2017.

Source: primary data of the study

Based on table 11 shows from 25 respondents, as many as 15 respondents $(83.3 \%)$ have good norms and behave on adequate postpartum care category. From Chi-Chi test result got $\rho=0,35$ where $\rho>\alpha$ $(0,05)$ so that $\mathrm{H} 0$ is accepted meaning that there is no influence between subjective norm with mother behavior on post partum care.

c. Cross tabulation Perception Controlling Ability with Respondent Behavior

Table 12 Distribution of Respondents With Perceptions of Mother Control
Ability in

Postpartum

Mother Behavior at RS Ibu Anak Fauziah

Tulungagung On 16 August to 16 September 2017.

Source: primary data of the study

Based on table 12 shows from 25 respondents, as many as 10 respondents (55.6\%), have perceptions of good control ability and behave on postpartum care enough category. From Chi Square test results obtained $\rho=0.12$ where $\rho>\alpha(0.05)$ so that $\mathrm{H} 0$ is accepted which means that there is no influence between the perception of the ability to control with the mother's behavior on post partum care.

\section{d. Tabulate Cross Interests With Respondent Behavior}

Table 13 Distribution of Respondents With Mother Interest In Postpartum Mother Behavior at RS Ibu Anak Fauziah Tulungagung On 16 August to 16 September 2017.

\begin{tabular}{|c|c|c|c|c|c|c|c|c|}
\hline \multirow{4}{*}{$\begin{array}{l}\text { Subjective } \\
\text { Normal } \\
\text { Category }\end{array}$} & \multicolumn{6}{|c|}{ behavior of respondents } & \multirow{3}{*}{\multicolumn{2}{|c|}{ Total }} \\
\hline & \multirow{2}{*}{\multicolumn{2}{|c|}{$\begin{array}{l}\text { Less } \\
\leq 55 \% \\
\end{array}$}} & \multirow{2}{*}{\multicolumn{2}{|c|}{$\begin{array}{c}\text { Enough } \\
56 \%-74 \%\end{array}$}} & \multirow{2}{*}{\multicolumn{2}{|c|}{$\begin{array}{c}\text { Less } \\
\geq 75 \% \\
\end{array}$}} & & \\
\hline & & & & & & & & \\
\hline & $\mathrm{N}$ & $\mathrm{F}$ & $\mathrm{N}$ & $\mathrm{F}$ & $\mathrm{N}$ & $\mathrm{F}$ & $\mathrm{N}$ & $\mathrm{F}$ \\
\hline Well & 1 & 100,0 & 15 & 83,3 & 4 & 66,6 & 20 & 80,0 \\
\hline Enough & 0 & 0,0 & 3 & 16,7 & 1 & 16,7 & 4 & 16,0 \\
\hline Less & 0 & 0,0 & 0 & 0,0 & 1 & 16,7 & 1 & 4,0 \\
\hline $\begin{array}{l}\text { Total } \\
\rho=0,35\end{array}$ & 1 & 100,0 & 18 & 100,0 & 6 & 100,0 & 25 & 100,0 \\
\hline
\end{tabular}

Source: primary data of the study

Based on table 13 showing from 25 respondents, as many as 15 respondents $(83.3 \%)$ have high interest and behave on postpartum care enough 


\begin{tabular}{|l|l|c|c|c|}
\hline \multirow{2}{*}{ Variabel } & \multicolumn{2}{|c|}{ MODEL 1 } & \multicolumn{2}{c|}{ MODEL 2* } \\
\cline { 2 - 5 } & Koef & $\rho$ & Koef & $\mathrm{P}$ \\
\hline $\begin{array}{l}\text { level of } \\
\text { education }\end{array}$ & 2,78 & 0,11 & 2,49 & 0,05 \\
\hline attitude & 2,05 & 0,18 & 1,91 & 0,17 \\
\hline perception & 0,30 & 0,80 & & \\
\hline$\rho$ & 0,09 & 0,04 \\
\hline $\mathbf{R}^{2}$ & 23,28 & 23,03 \\
\hline AIC & 29,14 & 27,20 \\
\hline$*$ Goodness of fit & $\begin{array}{l}\text { category. From result of Chi } \\
\text { square test got } \rho=0,96 \\
\text { where } \rho>\alpha \text { (0,05) so that H0 } \\
\text { is accepted meaning that } \\
\text { there is no influence between } \\
\text { interest } \\
\text { behavior on post partum } \\
\text { care. }\end{array}$
\end{tabular}

RESULTS OF STATISTICAL TESTS
1. Bivariate Statistics Test Results
Table 14 Bivariate Statistics Test Results

\begin{tabular}{lc}
\hline \multicolumn{1}{c}{ Variabel } & $\mathrm{P}$ \\
\hline level of education & $0,03^{*}$ \\
Work & 0,88 \\
age category & 0,37 \\
Attitude & $0,08^{\wedge}$ \\
perception & $0,12^{\wedge}$ \\
Norm & 0,35 \\
Interest & 0,96 \\
\hline$* \rho<0,005$ meaning meaningful \\
$\wedge \rho<0,25$ selected variables in \\
\multicolumn{2}{l}{ multivariate analysis } \\
\hline Source: primary data of the study
\end{tabular}

Source: primary data of the study

Table 14 shows that of the seven variables, after a bivariate statistical test, there is only one variable affecting postpartum care behavior, where chi square test results obtained $\mathrm{p}=0.03$ where $\mathrm{p}<\alpha$ (0.05) so that H0 rejected which means that there is an influence between the level of education in behavior on postpartum care at Fauziah Tulungagung Children's Hospital.

2. Multivariate Statistics Test Result Tabel 15 Hasil Uji Statistik Multivariat Dengan Metode Enter

Source: primary data of the study

Based on the table 15 multivariate test results obtained:

a. Model 1

The three selected variables are entered simultaneously. Of the three variables, able to predict the mother's behavior on postpartum care $23,28 \%$, while the rest equal to $76,72 \%$ caused by other risk factor not mentioned in this research.

b. Model 2 Only use 2 variables, by removing the variable with the largest nilai value. Model 2 shows the level of education is the most dominant variable affecting the mother's behavior on postpartum care and has a statistical significance. Model 2 was selected as the best model for predicting maternal behavior in postpartum care at RSIA Fauziah Tulungagung. Logistic Regression Equation (Model 2)

$\mathrm{Y}=2,49$ level of education $+1,91$ attitude+ 0,00 norm $+0,00$ interest $+0,00$ perception 


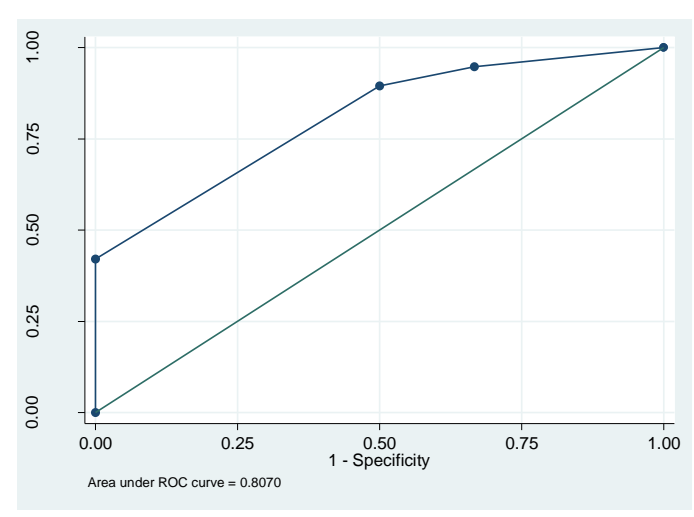

Figure 1

Logistic Regression Lines Goodness of Fit

AUC value $0.7 \mathrm{~s} / \mathrm{d}<0.8$ means the regression model obtained with a value of $\rho=0.77$ means $77 \%$ satisfactory.

\section{DISCUSSION}

\section{Level of Education in Maternal Behavior in Postpartum Care}

Based on the analysis, 25 respondents mostly 16 respondents (64\%) have high school education and 1 respondent (4\%) have elementary education.

According to Soekanto (2010), there are several factors that influence knowledge such as education level and age. Education is an attempt to provide knowledge so that there can be a change in positive behavior that increases.

Based on the above facts and theories, researchers agree that knowledge is closely related to education. People who have higher education are expected to have extensive knowledge and information skills better also so as to improve the positive attitude, which automatically also affect behavior.

2. Types of Work In Mother's Behavior In Postpartum Care

Based on the analysis show from 25 respondents, as many as 9 respondents $(50 \%)$ as IRT behave on sufficient category postpartum care.

The work according to Thomas cited by Nursalam (2003), is a need that must be done primarily to support his life and family life. Work is not a source of fun, but it is a way of earning a livelihood, repetitive and many challenges.

Concluding from the results and theories already described above, jobs generally require social relationships between one another, each person must be able to mingle with peers, superiors so that people with wide social relationships will be higher knowledge compared with people who have less relationship social with others. While the type of work, usually indicates the level of education that belongs, and education itself affects the knowledge it has, although this is not always true.

3. Age In Mother's Behavior In Postpartum Care

Based on the analysis show from 25 respondents, as many as 17 respondents $(94 \%)$ aged $>30$ years, bertilakupada postpartum care enough category.

Age affects a person's capture and pattern. Increasingly aged will also develop the ability to catch and the mindset, so the knowledge gained more and more (Notoatmodjo, 2003).

Concluding from the results and theories already described above, age generally affects the capture and pattern of one's mind. Increasingly aged will also develop the ability to catch and the mindset, so the knowledge gained more and more. Usually age will affect the treatment of postpartum mothers.

\section{Sikap Ibu Dalam Perilaku Perawatan Postpartum}


Berdasarkan analisis menunjukkan dari 25 responden, sebanyak 9 responden $(50 \%)$ mempunyai sikap positif dan negatif serta berperilaku pada perawatan postpartum kategori cukup, dan sebanyak 12 responden $(66,7 \%)$ berpendidikan SMA.

Pembentukan sikap dipengaruhi oleh berbagai faktor internal dan eksternal. Faktor faktor tersebut antara lain pengetahuan tentang obyek, pendidikan, fikiran negatif tentang obyek, orang atau kelompok yang mendukung, media komunikasi, dan lingkungan (Sarwono, 2012).

Berdasarkan fakta dan teori yang ada, peneliti sependapat bahwa selain penyuluhan, pendidikan juga mempengaruhi pengetahuan yang merupakan faktor yang sangat berpengaruh dalam penentuan sikap. Pendidikan SMA termasuk dalam pendidikan menengah mempunyai kemampuan mengadakan hubungan timbal balik dengan masyarakat, lingkungan sosial, budaya dan alam sekitarnya.

5. Mother's Attitude In Postpartum Care Behavior

Based on the analysis indicated from 25 respondents, 9 respondents $(50 \%)$ had positive and negative attitude and behaved on postpartum care enough category, and as many as 12 respondents $(66,7 \%)$ had high school education.

The formation of attitudes is influenced by various internal and external factors. Factors such factors include knowledge of objects, education, negative thoughts about objects, people or groups that support, communication media, and the environment (Sarwono, 2012).

Based on existing facts and theories, the researchers agree that in addition to counseling, education also affects knowledge that is a very influential factor in the determination of attitudes. High school education included in secondary education has the ability to establish mutual relationships with the community, social environment, culture and natural surroundings.

6. Subjective Maternal Moms In Postpartum Care Behavior

Based on the analysis show from 25 respondents most of which are 20 respondents $(80 \%)$ have good subjective norm, and behave on postpartum care enough category.

Subjective Norms are individual perceptions of social influences in shaping certain behaviors (Ajzen 1981 in Mutikasari 2007). So this subjective norm affects many decisions that will be taken by someone in determining the action.

From the results and the theory above, it appears that an individual will tend to conduct behavior if motivated by others who approve it to perform the behavior. The more a person sees their environment in favor of a behavior, the individual is increasingly feeling the social pressure to elicit such behavior, where routine counseling is conducted in the hospital, they regard it as a positive and necessary thing to do.

7. Perceptions of Maternal Behavior Control in Postpartum Care Behavior

Based on the analysis show from 25 respondents, as many as 10 respondents $(55,6 \%)$, have perception of ability to control good and behave on postpartum care enough category.

Beliefs that the individual has ever performed or never exercised a particular behavior, the 
individual has the facility and time to perform the behavior, then the individual estimates his or her ability whether or not he has the ability to carry out the behavior. Ajzen (2005) named this condition the "perceived behavioral control" (perceived behavioral control).

From the facts and theories that have been described, can penelitisimpulkan that one will perform a behavior determined by the past experience of the individual and also the individual estimates of how difficult or easy to perform a behavior. The behavior of a person is not only controlled by himself, but also requires control, namely the belief about the presence or absence of factors that facilitate and prevent individuals to perform a behavior.

\section{CONCLUSION}

1. Mother's Attitude In Postpartum Care Behavior

Whereas from 25 respondents, as many as 9 respondents $(50 \%)$ had positive and negative attitudes and behaved in sufficient category postpartum care. From result of Chi square test got $\rho=0,18$ where $\rho>\alpha$ $(0,05)$ so that $\mathrm{H} 0$ is accepted meaning that there is no influence between attitude with mother behavior on post partum care.

2. Subjective Maternal Moms In Postpartum Care Behavior

Whereas from 25 respondents, a total of 15 respondents $(83.3 \%)$ had good norms of behavior and behaved in sufficient category postpartum care. From Chi-Chi test result got $\rho=0,35$ where $\rho>\alpha$ $(0,05)$ so that $\mathrm{HO}$ is accepted meaning that there is no influence between subjective norm with mother behavior on post partum care.
3. Perceptions of Maternal Behavior Control in Postpartum Care Behavior

Whereas from 25 respondents, as many as 10 respondents (55.6\%), have perceptions of good controlling ability and behave on sufficient category postpartum care. From Chi Square test results obtained $\rho=0.12$ where $\rho>\alpha(0.05)$ so that $\mathrm{H} 0$ is accepted which means that there is no influence between the perception of the ability to control with the mother's behavior on post partum care.

4. Mother's Interest In Postpartum Care Behavior

Whereas from 25 respondents, a total of 15 respondents $(83.3 \%)$ had high interest and behaved in sufficient category postpartum care. From result of chi square test got $\rho$ $=0,96$ where $\rho>\alpha(0,05)$ so that $\mathrm{H} 0$ is accepted meaning that there is no influence between interest with mother behavior on post partum care.

5. The Most Dominant Factor

Whereas based on chi square test the most dominant factor is education level, where $\mathrm{p}=0,03$ where $\mathrm{p}<\alpha$ $(0,05)$ so that $\mathrm{HO}$ is rejected which means that there is influence between education level in behavior on postpartum care at Rumah Sakit Ibu Anak Fauziah Tulungagung.

\section{BIBLIOGRAPHY}

Arwanti, Ni M. S. 2009. Swadharma Mother in Hindu Family. Jakarta: Gramedia Pustaka Utama.

Ajzen, I. 2005. Attitudes, Personality and Behavior. New York. USA: University Press.

Bobak; Lowdermilk; Jensen. 2005. Maternity Nursing Teaching 
Book. Ed. 4. Language translation: Renata Komalasari. Jakarta: EGC.

Ghozali, Imam. 2011. Application of Multivariate Analysis With SPSS Program. Semarang: Diponegoro University Publishing Agency.

Hartono, Jogiyanto. 2007. Success Model of Information Technology System. Yogyakarta: Andi Publisher.

Herawati. 2010. Relationship of Perineal Care With Wound Healing. Perineum In Mother Nifas Day Sixth In Private Midwives Practice Ny. Sri Suhersi Mojokerto Kadawung Sragen. Sebelas Maret University Surakarta.

Hidayat, Aziz A. 2007. Research Methods and Data Analysis Techniques. Jakarta: Salemba Medika.

Ine. 2010. Bleeding Causes Maternal Death.

http://kesehatan.kompas.com/re $\mathrm{ad} / 2010 / 01 / 30 / 0746890 /$ perdara han.penyebab.kematian.ibu. obtained on February 20, 2017.

Ismail, V. Y., \& Zain, E. 2008. The Role of Attitudes, Subjective Norms, and Perceived. Behavioral Control of High School Students Intensi to Select Faculty. Jakarta: Salemba. Liabsuetrakul, Vitayanout and Pitanupong. 2007. Clinical Applications of Anxiety, Social Support, Stressors, and SelfEsteem for Postpartum Depression in Thai Women. 2df1-4214-8048d051eb27e09\%. Was obtained on February 27, 2017.
Mansur, H \& Budiarti, T. 2014. Maternal and Child Psychology For Midwifery. Jakarta: Salemba.

Notoatmodjo, Soekidjo. 2010. Health Behavioral Science. Jakarta: Rineka Cipta.

Nursalam. 2007. Nursing Management and Its Application. Jakarta: Salemba.

Reitmanova and Gustafson. 2007. They Can not Understand It: Maternity Health and Care Needs of Immigrant Muslim Women in St. John's,

Newfoundland.http: //www.springerlink.com/conten t/h27870q6037t2113/fulltext.pd f. obtained by February 27, 2017.

Runiari, N. 2005. Perception of Nurse, Postpartum and Family Mom About Matter Priority and Postpartum Feeding Method of RSUP Fatmawati Year 2005. Thesis. Not published.

Saleha, Sitti. 2009. Midwifery Care At Babylon Period. Jakarta: Salemba Medika.

Sastroasmoro, Sudigdo, and Sofyan Ismael, 2010. The Basics of Clinical Research Methodology of the third edition. In: Selection of Research Subjects and Design Research. Jakarta: Sagung Seto.

Setiadi. 2007. Concept and Writing of Nursing Research. Yogyakarta: Graha. Science.

Setiawati, Generous. 2008. Learning Process In Health Education. Trans Media Info: Jakarta. 
Soekanto, Soerjono. 2009. The Role of Sociology An Introduction, New Edition. Jakarta: Rajawali Pers.

Sugiyono. 2008. Educational Research Methods

Quantitative Approach, Qualitative, and R \& D. Bandung: Alfabeta.

Susilo, Rakhmat. 2011. Health Education In Nursing. Bantul: Kuha Medika.

Teo, T. \& Lee C. B. 2010. Examining the efficacy of the Theory of Planned Behavior (TPB) to understand pre-service teachers' intention to use technology. Singapore: Nanyang Technology University.

Wong, D.L., Perry, S.E., Hockenberry, M.J. 2002. Maternal Child Nursing Care. Second edition.USA: Mosby.Inc.

Yuliana. 2004. The influence of attitudes toward job change, subjective norm, perceived behavioral control on the intention of moving to work in information technology workers. Phrones: Scientific Journal of Applied Psychology, 6 (11), 1-18. 